\title{
Not Just a Man of Guns: Chen Jiongming, Warlord, and the May Fourth Intellectual (1919-1922)
}

After the Great War, the young Chinese Republic faced not only increasing civil conflicts and territorial divisions among the regional military-political strongmen, who were commonly known as warlords, but also radicalized intellectual movements seeking reforms across all levels of society. Dissatisfied with China's subordinate position in the post-war world and with the weakness of the Beiyang government controlled by warlords, the leading intellectuals of China, most of whom had studied in the West or Japan, raised the banner of "democracy and science" on the one hand, and that of "anti-warlordism, anti-imperialism" on the other. As initiators of the New Culture and May Fourth movements, the May Fourth intellectual were henceforth perceived as a sturdy opposition to those "culturally backward and politically reactionary militant tyrants". The dichotomy between May Fourth nationalism and warlordism was further reinforced in the revolutionary narratives of both the Nationalist Party (Kuomintang 國民黨, hereafter KMT) and the Chinese Communist Party (Gongchandang 共 産黨, hereafter the CCP), who quickly associated warlordism with "feudalism" - a term in its Chinese context connoted all the problems and evils of traditional, despotic rule - and who claimed the National Revolution (1924-1927) to be the only solution to the endless civil wars, military fragmentation, political disorder, and economic instability in warlord China.

“Warlord” (junfa 軍閥) has always been a problematic category for understanding modern Chinese history. While this term frequently appeared in contemporary writings of the warlord period, as Winston Hsieh notes, no one ever called himself a warlord. The term was always reserved for a bad military leader or applied to one's enemies. ${ }^{1}$ Highly aware of the trouble of terminology, scholars have pointed out the necessity of shifting from an essentialist, pejorative connotation of "warlord" to a constructivist view that perceives "warlord" as a constructed identity subject to changes within different contexts. ${ }^{2}$ Terms that are comparatively neutral, notably "militarist", are thus preferred by some Western scholarship to characterise the regional strongmen who possessed various sources of power over the territory of either one province or several provinces in early twentieth-century China. ${ }^{3}$ This article, adopting a new term "man of guns" (wuren 武人), will avoid using the term "militarist" for the following two reasons: First, "militarism" itself is a difficult concept bearing different connotations in its Western contexts, while "man of guns" is a native term that has been frequently used in contemporary writings and that conveys specific meanings to contemporaries. ${ }^{4}$ Second, "man of guns" is the only term

\footnotetext{
${ }^{1}$ Winston Hsieh, "The Ideas and Ideals of a Warlord: Ch'en Chiung-ming”, Papers on China, no. 16 (1962), 199; Hsi-Sheng Chi, Warlord Politics in China, 1916-1928 (Stanford, California: Stanford University Press, 1976), 1.

2 Izabella Goikhman, "Chen Jiongming, Becoming a Warlord in Republican China" in State, Society and Governance in Republican China, edited by Mechthild Leutner and Izabella Goikhman (Münster: LIT Verlag, 2014), 77-101.

${ }^{3}$ Chi, Warlord Politics in China, 1916-1928, 1; Anthony B. Chan, Arming the Chinese: The Western Armaments Trade in Warlord China, 1920-28 (Vancouver: UBC press, 1982), XXVI.

${ }^{4}$ Apart from “man of guns”, “dujun” 督軍 and “governor” (shengzhang, 省長) are also terms frequently used in contemporary writings. However, different from "man of guns", "dujun", and "governor" are both names of the positions commonly obtained by Chinese regional strongmen from various governments.
} 
that juxtaposes the regional and local military strongmen with the "man of letters" (wenren, 文 人) of the May Fourth period, and thus provides this research with a precise category through which the complex relationships between warlords and the May Fourth intellectual, as well as between warlordism and the Chinese enlightenment, could be contextualized. ${ }^{5}$

While the existing Western scholarship devotes great attention to warlord military organizations, manoeuvres, and conflicts, it does not echo the Chinese Nationalist/Communist historiography in depicting warlords simply as militant tyrants and thus the obstacles of modern state-building. ${ }^{6}$ As McCord puts it, the authority of the military strongmen in some provinces was "based more in their adjustment to, and manipulation of, civilian politics than on their control of military force". ${ }^{7}$ In line with McCord's comments on the "elite and civil nature" of some Chinese warlord regimes, Ronald Suleski focuses on the institutional, administrative and economic development during the warlord period, demonstrating that warlord rule features both elements of the Chinese autocratic tradition and the Western-style modernization. ${ }^{8}$ However, this scholarship, having overemphasized the pragmatic functionality of warlord governance, significantly underestimates the ideological elements of warlordism as well as the intellectual pursuits of those so-called warlords. It has been taken for granted that, "Skill in violence had forced out the power of enlightenment." 9 Although some scholars have recognized the beliefs, values, and norms formulated and disseminated by warlords, they are still prone to consider warlord ideologies as fragmented doctrines that were used to reinforce their military control, and that were soon to be overshadowed and replaced by the KMT

\footnotetext{
${ }^{5}$ I use the term "Chinese enlightenment" in this article to refer to not only the individual, cultural and intellectual engagement with self-emancipation, but also the collective, social and political embracement of national salvation and state-building among educated Chinese elites since the nineteenth century. The New Culture and May Fourth movements saw the summit of, as well as intensive interactions between, these two processes. For more scholarly approaches to the Chinese enlightenment, please see Vera Schwarcz, The Chinese Enlightenment (Berkeley and Los Angeles, California: University of California Press, 1986), 1-11\& 94-144; Wei Zhang, What Is Enlightenment: Can China Answer Kant's Question? (Albany: State University of New York Press, 2010), 29-44.

${ }^{6}$ The early study of the so-called warlord era (1916-1928) has been done mainly in the category of warlord biographical histories. Lucian Pye and Hsi-Sheng Chi are among the first historians who made effort to reveal the behaviour patterns of and relationships among warlords and to reflect on the political attributes and military dynamism of Chinese warlordism. While Anthony Chan integrates the international and military approaches to demonstrate warlord regimes' engagement with Western powers for armament, Edward McCord pays further attention to the constant interactions between "the politicization of military men" and "the militarization of politics" in the making of warlordism. Chi, Warlord Politics in China, 1916-1928, 4-5; Chan, Arming the Chinese, XXIII; Lucian W. Pye, Warlord Politics: Conflict and Coalition in the Modernization of Republican China (Santa Barbara, CA: Praeger, 1971); Edward A. McCord, The Power of the Gun: The Emergence of Modern Chinese Warlordism (Berkeley and Los Angeles, California: University of California Press, 1993).

${ }^{7}$ McCord, The Power of the Gun, 93.

${ }^{8}$ McCord, The Power of the Gun, 151. Ronald Suleski, Civil Government in Warlord China: Tradition, Modernization and Manchuria (New York: Peter Lang Publishing, 2002).

${ }^{9}$ Pye, Warlord Politics, 155.
} 
nationalist creed. ${ }^{10}$ As a result, warlordism has seldom been perceived as a constitutive part of the dynamics - rather than simply the antithesis - of the New Culture and May Fourth movements. As Mary Rankin interprets, on the one hand, warlordism was targeted by the revolutionaries who claimed to defend their "ideals of nationalism, republicanism, and democracy", and on the other hand, it was also attacked by civil elites and intellectuals who had achieved some limited political autonomy under the system but still demanded more. ${ }^{11}$ Given the constructed dichotomy between the man of guns and the man of letters, the historiography of Chinese warlordism and that of the Chinese enlightenment have seldom incorporated one another, regardless of the inextricable relationships between the two.

Zhongping Chen's research sheds some light on the paradoxical relationship between the May Fourth Movement and Chinese warlords, showing that many warlords, due to their patriotic sentiment if also ulterior political motives, supported student movements - the May Fourth Movement could achieve its final successes because it incorporated the varied personal, parochial, and factional interests of these regional leaders into a broad nationalist platform. ${ }^{12}$ Winston Hsieh's study of the ideas and ideals of Chen Jiongming 陳畑明, the regional leader of Guangdong, demonstrates Chen's passionate embracement of the newly imported Western ideas such as social Darwinism and anarchism as well as his firm support to the New Culture Movement, albeit his seemingly tenacious adherence to the Confucian elitist tradition. However, in Hsieh's interpretation, such abiding attachment to tradition eventually prevented warlords from truly endorsing bottom-up democratic movements and proletarian revolutions. ${ }^{13}$ While these scholarly efforts have already helped demonstrate that the warlord rule can be conterminous with May Fourth nationalism and New Culture innovation, they still fall short. Instead of further elucidating such "conterminous-ness", the existing scholarship tends to reach a plausible but simplistic conclusion that those "enlightened" regional leaders were, after all, traditional-minded rulers whose ultimate goal was still to achieve unification of the nation through their own effective rule - in a paternalistic, benevolent manner at best.

It thus remains unclear to what extent we can claim that warlords were not only military leaders, civil governors, and occasional sympathisers to nationalist movements, but also important proponents of the Chinese enlightenment - and moreover, to what extent we can claim that Chinese warlordism was not only conterminous with, but also conducive to, the ideological, intellectual and cultural innovations of the New Culture and May Fourth movements. Political competition and military fragmentation during this period allowed a crucial space for dynamic interactions among different socio-political groups, movements, and ideas thriving across regional and national borderlines. The prevalent trends of, not only nationalism, but also anarchism, socialism, and federalism, engaged both China's enlightenment thinkers and those regional strongmen in search of different paths towards peace, modernity, and development. Situating the study of warlordism against the backdrop of the May Fourth Movement, this article examines the prevailing idea exchange and political collaboration between the southern military strongman Chen Jiongming and the May Fourth intellectual between 1919 and 1922.

\footnotetext{
${ }^{10}$ Donald G. Gillin, Warlord: Yen Hsi-Shan in Shansi Province, 1911-1949 (Princeton, New Jersey: Princeton University Press, 1967), 59-78; Chi, Warlord Politics in China, 54-56.

${ }^{11}$ Mary Backus Rankin, "State and Society in Early Republican Politics, 1912-1918”, in Reappraising Republican China, edited by Frederic Wakeman, Jr. and Richard Louis Edmonds (New York: Oxford University Press, 2000), 8.

${ }^{12}$ Zhongping Chen, "The May Fourth Movement and Provincial Warlords: A Reexamination", Modern China 37, no. 2 (2011), 163.

${ }^{13}$ Hsieh, “The Ideas and Ideals of a Warlord: Ch'en Chiung-ming", 198-251.
} 
And by so doing, it attempts to downplay the differences between the man of guns and the man of letters, and thereby to redefine, recharacterize and reappraise Chinese warlords as active agents - the initiators - of China's renewals during this formative period.

Chen Jiongming was a regional strongman who advocated anarchism, socialism, and federalism for the making of a modern Guangdong, and who developed extensive politicalintellectual ties with the May Fourth intellectual both within and beyond regional borders. However, due to his dramatic breakup with Sun Yat-sen 孫中山 through a coup d'état against Sun in 1922, Chen was denounced by the KMT and discredited by Sun as a "malignant and wicked-hearted enemy, a traitor to the KMT, and a misfortune of the Republic". ${ }^{14}$ As soon as the first KMT-CCP United Front was envisioned under the guidance of the Comintern, the revolutionary discourses endorsed by both the KMT and the CCP further perpetuated Chen's image as a feudalist warlord and a national traitor. ${ }^{15}$ Thanks to Chen Dingyan 陳定炎 (also known as Leslie H. Dingyan Chen), Chen Jiongming's son, who collected a multitude of firsthand historical materials and published exhaustively on his father in the 1980s and 1990s, Chen Jiongming's ideological concerns and intellectual pursuits are now better recognized. Despite the likely biases owing to a son's love for his father and motive to redeem his father's reputation, Chen Dingyan's work has provided valuable sources and inspirations for scholars to rethink the ideological and intellectual aspects of Chinese warlordism.

Prasenjit Duara, John Fitzgerald, and Izabella Goikhman have identified Chen Jiongming's federalist ideas and reformist intentions, which, they argue, eventually led to the final split between him and Sun Yat-sen in $1922 .{ }^{16}$ However, while this revisionist scholarship displays the complex ideological and power contests in Guangzhou prior to the National Revolution, it still mainly concerns itself with the tension between Chen and Sun, or that between the localregional institutions and the national ones represented by the KMT-CCP alliance. Still underresearched is how the multiple political and intellectual forces present in Guangzhou between 1919 and 1922 - the Nationalists under Sun, the Marxists led by Chen Duxiu 陳獨秀, the anarchists represented by Liang Bingxian 梁冰弦, as well as Chen Jiongming - identified themselves with the May Fourth Movement, the revolution, and more importantly, with one

${ }^{14}$ On 16 June 1922, in the name of "restoring the Constitution and removing illegitimate presidents" (which referred to both Xu Shichang of the Beiyang government and Sun Yat-sen of the Guangzhou government), Chen Jiongming's army attacked Sun's headquarters and residence in Guangzhou. Sun escaped to the warship Yongfeng. Having failed to put down the rebellion, Sun and his followers were driven out of Guangzhou aboard a British gunboat bound for Hong Kong, then a Russian boat for Shanghai. It was not until January 1923 that Sun was able to wipe away the humiliation by defeating Chen with the help of the so-called Anti-Evil Army (Taozeijun 討賊軍) comprising different warlord factions from Guangdong, Guangxi and Yunnan. John Fitzgerald, Awakening China: Politics, Culture, and Class in the Nationalist Revolution (Stanford, California: Stanford University Press, 1996), 148; Minguo Guangdong dashiji 民國廣東大事記, edited by Guangdong Provincial Library (Guangzhou: Yangcheng wanbao Press, 2002), 160; Leslie H. Dingyan Chen, Chen Jiongming and the Federalist Movement: Regional Leadership and Nation Building in Early Republican China (USA: University of Michigan Press, 1999), 2-3.

${ }^{15}$ Fitzgerald, Awakening China, 152-153.

${ }^{16}$ See Fitzgerald, Awakening China, 147-179; Goikhman, "Chen Jiongming, Becoming a Warlord in Republican China", 77-101; and Prasenjit Duara, Rescuing History from the Nation (Chicago and London: University of Chicago Press, 1995), 177-204. 
another. Guangzhou during the May Fourth was not only a place of contention, but also a space for communication and collaboration. Focusing on the anarchist-oriented Huiming Society (Huiming xueshe 晦明學社) and the Marxist-oriented Guangdong Qunbao 廣東群報 Society (hereafter Qunbao Society) - both supported by Chen Jiongming, this article attempts to gauge the nature, scope, style, and ramification of the intellectual exchange and political collaboration that unfolded between Chen Jiongming and the May Fourth intellectual in Guangzhou, and thereby to reappraise the varied roles of, and the ambiguous relationships between, the man of guns and the man of letters in the ideological, political and cultural formations of the new Chinese Republic.

\section{From an Anarcho-Socialist Mecca to a Federalist State}

In February 1921, Rodney Gilbert, an American journalist working for the renowned Englishlanguage newspaper North China Daily News, went to Guangzhou, the capital city of Guangdong Province, to interview the civil governor of Guangdong, Chen Jiongming. ${ }^{17}$ As a matter of fact, "civil governor" was neither the only nor the most prominent title Chen had earned through his intellectual, political and military life. In 1898, at the age of 20, Chen obtained a Xiucai degree after having received the traditional Confucian education. Like most Chinese intellectuals at the time, Chen was deeply influenced by the Late Qing reform ideas of Western Learning; so instead of continuing the Confucian education, he enrolled in the Guangdong Academy of Law and Politics, a modern technician school that taught the up-todate Western ideas and methods. In 1909, when he was only 30 years old, Chen Jiongming was already an elected delegate to the Guangdong Provincial Assembly (Guangdongsheng ziyiju 廣東省咨議局). And using his position, he not only provided financial support to Sun Yatsen's anti-Qing movement in and out of China, but also led a Cantonese revolutionary army during the 1911 Revolution. ${ }^{18} \mathrm{He}$ was then seen by his contemporaries as a staunch revolutionary patriot, a heroic figure whose efforts have helped topple China's last monarchy. After the revolution, Chen maintained one of the strongest forces in Guangdong under his own command. In the civil conflicts between 1917 and 1920, he allied with Sun, mastering various military manoeuvres while helping Sun consolidate his position in South China. Thanks to his military triumphs over the Guangxi warlord factions occupying Guangdong, Sun was able to claim a military-revolutionary government in Guangzhou in November 1920, in opposition to the Beiyang government. ${ }^{19}$ As a triumphant general, and as the local protector, Chen Jiongming then held real military power within the Guangzhou government, and was thus appointed by Sun both the governor of Guangdong and the commander-in-chief of the Cantonese army. ${ }^{20}$

However, when Rodney Gilbert commented on Chen Jiongming, he has not once associated Chen's name with warlordism, nor did he focus on the continuous civil wars that involved Chen. Instead, Gilbert saw his visit as a pilgrimage and perceived Chen Jiongming as a civil governor, a reformer, if also a philosopher. Clearly what has impressed this Western journalist was not Chen's military conquests, but his innovative views on local reform and his ambitious scheme for building a federalist China:

\footnotetext{
${ }^{17}$ Minguo Guangdong dashiji, 130.

${ }^{18}$ Goikhman, "Chen Jiongming, Becoming a Warlord in Republican China", 79.

${ }^{19}$ Chen, Chen Jiongming and the Federalist Movement, 58-65 \& 97-104. Goikhman, "Chen Jiongming, Becoming a Warlord in Republican China", 79-82.

${ }^{20}$ Minguo Guangdong dashiji, 124.
} 
We are beginning with villages and organizing them into sub-districts under committee rule. When all the sub-districts have been organized and are self-governing, policing themselves and collecting their own taxes, we propose to have the county magistrates and other local offices, as well as delegates to the provincial assembly, chosen by popular election.

$[\ldots]$

We believe that if we begin the application of our ideas in Guangdong and if we are at all successful, the example will prompt the people of the province around us to insist upon a similar system and that the movement will spread throughout China. If we can get a few provinces we can federate and bring in the others, one by one, until we have made China over into a government of united provinces. ${ }^{21}$

The reason for initiating such federalist reform is because, as explained by Chen:

Each of the northern leaders who has tried to restore order has worked under the spell of the old monarchical tradition of a single autocratic head to the state and has set out to unite China by subduing his opponents and by centralizing all power in himself. [...] Yuan Shikai 袁世 凱 tried to make the Republic conform to the old monarchical model and failed. [...] Dr. Sun Yat-sen has also sought at times to unite China by conquests and has always failed. It ought to be apparent by this time that no individual and no group of persons who proposes to experiment further in conquests by force of arms should be trusted with power. ${ }^{22}$

In this regard, Chen Jiongming's political ideas and reform plans not only were distinct from that of the northern military leaders, but also departed from that of the revolutionary leader Sun Yat-sen. Despite having showed enthusiasm for local self-governance and flirted with federalist ideas, Sun in early 1921 was determined to consolidate absolute personal leadership, carry out political tutelage, and jumpstart the Northern Expedition in attempting to unify the country by force of arms. ${ }^{23}$ It would not be too bold to argue that, at least in Chen Jiongming's own eyes, he, not Sun Yat-sen, was a real crusader against the ills of warlordism, that is, against obtaining and maintaining power through military conquest, political autocracy, and cultural conservatism.

Although Chen Jiongming had assisted Sun Yat-sen in the 1911 Revolution to overthrow the Manchu monarchy, this time, when Sun tried to persuade him to come on board for the "antiwarlordism" expedition, he refused. The deepening antagonisms between the two leaders in Guangzhou have been studied by scholars, who concluded that it was the ideological difference rather than personal grievance that resulted in their final split. But what were the origin, essence, and purpose of Chen Jiongming's ideas? And most importantly, how did he try to materialize his ideas through communicating and networking with the intellectual elites in the South - who hailed from across a wide political-intellectual spectrum, but whose shared impulse to realise a new culture would soon present a great challenge to the power base of Sun Yat-sen?

21 "A Pilgrimage to Canton - An Interview with General Chen Jiongming", South China Morning Post, 23 February 1921, 7.

22 "A Pilgrimage to Canton".

23 “Zai Hu juban chahuahui de yanshuo” 在滬舉辦茶話會的演說, 17 July 1916, in Sun

Zhongshan quanji 孫中山全集 Volume 3 (Beijing: Zhonghua shuju, 1981), 327-330;

“Guangzhou tongxin” 廣州通信, Shenbao, 12 December 1920, 2. 
When the May Fourth Movement broke out in 1919, Chen Jiongming, as the commander-inchief of the Aid-Fujian Cantonese Army (Yuanmin yuejun 援閩粤軍), was directing a military expedition in Fujian, a neighbouring province to the northeast of Guangdong. ${ }^{24}$ He stationed his troops and established his military headquarters in Zhangzhou, a small town in southern Fujian. In the area under his control, Chen Jiongming carried out various reforms to improve education, administration, public health, security, and transportation. More importantly, he invited a group of anarcho-socialist thinkers to assist with his local reforms and sponsored approximately 80 young intellectuals to advance their education in France, America, Britain, and Japan. ${ }^{25}$ In the eyes of Zheng Chaolin 鄭超麟, one of the students sponsored by Chen to study in France, Chen Jiongming was a new-style army man who preached socialism and even anarchism:

As soon as he got to Zhangzhou, he built carriageways in the city, opened a park, and started running athletics meetings and publishing a daily newspaper. Rickshaw-pullers were banned from the highway; a stone obelisk was placed in the park inscribed with the words "Freedom", “Equality", "Fraternity", and “Mutual Aid". Here, the anarchist influence of Wu Zhihui 吳 稚晖 and Li Shizeng 李石曾 is discernible. To chime in with $\mathrm{Wu}$ and Li's work-study programme, Chen Jiongming ordered each county magistrate in the region under his jurisdiction to send two or three people to France to study. ${ }^{26}$

Wu Zhihui and Li Shizeng were both influential members of the World Society (Shijie she, 世 界社), a cultural and revolutionary publishing house founded in 1906 by a group of Chinese anarchist intellectuals in Paris. Between 1915 and 1925, they promoted work-study programmes to help Chinese students to study in France. The purpose of these programmes was to make students finance their own study by working in local factories, and thereby to unify intellectual and manual work - a major step towards achieving mutual assistance, cooperation, and equality in society. ${ }^{27} \mathrm{He}$ Yan's research demonstrates the transnational affiliations attained by the World Society, not only with prominent May Fourth intellectuals such as Cai Yuanpei 蔡元培, but also with different levels of politicians serving in either the

\footnotetext{
${ }^{24}$ The Aid-Fujian Cantonese Army consisted of the twenty battalions that Chen Jiongming had formed and maintained through the 1911 Revolution, the War against Yuan Shikai, and the Constitution Protection Movement. In 1917, Sun Yat-sen, in the name of the ConstitutionProtection Military Government in Guangzhou, appointed Chen Jiongming the commanderin-chief of the Aid-Fujian Cantonese Army. In 1920, after Sun had established a second military government in Guangzhou, the Aid-Fujian Cantonese Army was generally referred to as the Cantonese army and Chen appointed the commander-in-chief of the Cantonese army. Ai Hong 艾虹, “Chen Jiongming yidu chengwei Su'e zaihua hezuozhe de yuanyin tanxi” 陳炣明一度成爲蘇俄在華合作者的原因探析, Changbai Journal, 01 (2011), 138139.

${ }^{25}$ Leslie H. Dingyan Chen, Chen Jingcun nianpu 陳競存年譜 (Taipei: Li Ao Press, 1995), 203-204.

${ }^{26}$ Zheng Chaolin, "Consciousness Awakes", in Prophets Unarmed: Chinese Trotskyists in Revolution, War, Jail, and the Return from Limbo, edited by Gregor Benton (Netherlands: Brill, 2014), 174-175.

${ }^{27}$ Paul Bailey, “The Chinese Work-Study Movement in France”, China Quarterly 115 (1988), 445.
} 
Beiyang government or the Guangzhou government. ${ }^{28}$ What Yan's research misses out is that, Chen Jiongming, the soon-to-be condemned "warlord", also constituted a nodal point of this transnational network for promoting work-study programmes. Not only had Chen fervently endorsed the establishment of L'institut franco-chinois de Lyon and a labour university in Belgium and donated 50,000 yuan directly to Cai Yuanpei for developing educational programmes for overseas Chinese students, but he also sponsored Cantonese students to enrol in work-study programmes in France annually. ${ }^{29}$

Employing popular European political ideas to fuel his local reform, Chen Jiongming openly made "liberty", "equality", "fraternity", and "mutual aid" - a confident, albeit convenient, combination of French revolutionary creed and Kropotkinian anarchist ideal - the motto of his own regime, and soon turned the region under his control into an anarcho-socialist Mecca. While $\mathrm{Wu}$ Zhihui and Li Shizeng, the prominent intellectuals who had well established themselves within the KMT and fostered extensive political-intellectual connections in Europe, became regular visitors, the native Cantonese anarchists, who formed a much younger and politically more independent group in Guangzhou, also quickly gravitated to Chen. ${ }^{30}$ In 1919 Chen Jiongming hired Liang Bingxian, a Cantonese anarchist thinker and the current leader of the Socialist League (Shehuizhuyi tongmeng 社會主義同盟) in Guangzhou, to head the Education Bureau of his military headquarters. ${ }^{31}$

In the summer of 1919, Liang Bingxian received letters from Chen Jiongming beseeching him as well as "some old friends of the Huiming Society" to come to join him in Zhangzhou. ${ }^{32}$ Founded by the prominent anarchist thinker Liu Shifu 劉師復 in Guangzhou in 1912, the Huiming Society was one of the earliest anarchist organizations in China. ${ }^{33}$ Liu died at a young age in the year of 1915, but his disciples in Guangdong, including Liang Bingxian, Huang Lingshuang 黃淩霜, and Ou Shengbai 區聲白, all joined Chen Jiongming around 1919 and 1920 with the hope of fulfilling their anarchist ideal. ${ }^{34}$ While studying at Peking University in the late 1910s, Huang Lingshuang and Ou Shengbai, despite their young age, had thoroughly explored the thoughts of Kant, Kropotkin, Bakunin, and Barett. They published their anarchist ideas in Beijing daxue xuesheng zhoukan 北京大學學生周刊 and actively engaged in

${ }^{28} \mathrm{He}$ Yan, "Overseas Chinese in France and World Society: Culture, Business, State and Transnational Connections, 1906-1949", in State, Society and Governance in Republican China, 51-53.

29 “Fu Chen Jiongming han” 復陳畑明函, 21 November 1920, in Cai Yuanpei wenji 蔡元培 文集 Volume 11 (Hangzhou: Zhejiang jiaoyu Press, 1998), 17.

${ }^{30}$ Zeng Qingliu 曾慶榴, “Chen Duxiu yu Chen Jiongming guanxi kaoxi” 陳獨秀與陳昫明關 系考析, Que Hai Feng 01 (2010),15; Chen, Chen Jiongming and the Federalist Movement, 88.

${ }^{31}$ Chen, Chen Jingcun nianpu, 203.

${ }^{32}$ Chen, Chen Jingcun nianpu, 213.

${ }^{33}$ Edward S. Krebs, Liu Shifu, Soul of Chinese Anarchism (Lanham: Rowman \& Littlefield, 1998), 101-102.

${ }^{34}$ Zhang Richi 張日池, “Wuzhengfu zhuyi huodong zai Guangzhou” 無政府主義活動在廣 州, 6 November 1964, in Guangzhou wenshi ziliao cungao xuanbian 廣州文史資料存稿選編. http://www.gzzXws.gov.cn/gzws/cg/cgml/cg5/200808/t20080827_5338.htm (accessed 7 August 2019) 
intellectual debates pertaining to anarchism. ${ }^{35}$ Under their influence, a number of university students from Beijing also travelled southward to observe and partake in Chen Jiongming's reform. They, as Goikhman puts it, found Chen to be "a man devoted to revolution" and his practices as good as those "in an age of communism" could ever be. ${ }^{36}$

Since Liang Bingxian's arrival, Chen Jiongming came to visit him on a daily basis. Regardless of whether it was early in the morning or late at night, Chen simply invited himself to Liang's residence, sat in the bamboo armchair and initiated their tête-à-tête on any subject. As a hospitable host, Liang entertained his guest with his extensive thoughts as well as some salted peanuts, fried chestnuts, or sesame candies. ${ }^{37}$ It was through these spontaneous but highly constructive conversations, Chen Jiongming became increasingly determined what role he should play not only in the heightened military and political manoeuvres but, more importantly, in this intellectual and cultural movement sweeping across China. In December 1919, with Chen's firm support, Minxing 閩星, a biweekly magazine dedicated to promoting new ideas and new culture, was launched. The team of editors and contributors comprised young Cantonese anarchist thinkers such as Liang Bingxian, Liu Shifu's brother Liu Shixin 劉石心, and Chen Qiulin 陳秋霖. ${ }^{38}$

It would be wrong to assume that the new-born Chinese Republic, lacking a strong central authority in the 1910s and 1920s, served as a free zone for circulating "radical ideas", that is, any ideas bearing the names or characteristics of anarchism and communism. In 1913, the publication of Huiminglu 晦明录, the organ of the Huiming Society, had already aroused suspicion among the Beiyang government. ${ }^{39}$ When Yuan Shikai's plan for imperial restoration loomed large, the government became even less tolerant of the rampantly spreading "heresies" across China. Orders were sent from both the Capital Police Bureau and the Department of Communications, urging provincial post offices to search carefully and intercept any suspicious publications aimed at promoting anarchism. ${ }^{40}$ In December 1920 , the State Council of the Beiyang government imposed a total ban on circulation of anarchist and communist publications. ${ }^{41}$ Most regional strongmen, especially the northern military leaders under the

\footnotetext{
35 “Huang Lingshuang yu Zhu Qianzhi taolun wuzhengfu gongchan zhuyi wen” 黃淩霜與朱 謙之討論無政府共產主義文, February 1920, in Zhongguo wuzhengfu zhuyi he zhongguo shehuidang 中國無政府主義和中國社會黨, edited by the Second Historical Archives of China (Nanjing: Jiangsu renmin Press, 1981), 35-48.

${ }^{36}$ Goikhman, "Chen Jiongming: Becoming a Warlord in Republican China", 82.

${ }^{37}$ Chen, Chen Jingcun nianpu, 215.

${ }^{38}$ Minguo Guangdong dashiji, 108.

39 “Zheng Rucheng guanyu micha Huiminglu zhi Jin Shaocheng han” 鄭汝成關於密查晦明 錄致金紹誠函, 26 December 1913, in Zhongguo wuzhengfu zhuyi he zhongguo shehuidang, $1-16$.

40 “Jingshi jingchating guanyu gesheng chajin Rendao xiang” 京師警察廳關於各省查禁人 道詳, 9 February 1916, in Zhongguo wuzhengfu zhuyi he zhongguo shehuidang, 16-18.

41 “Guowuyuan guanyu yanjin wuzhengfu zhuyi shukan chuanbo gonghan” 國務院關於嚴禁 無政府主義書刊傳播公函, 29 December 1920, in Zhongguo wuzhengfu zhuyi he zhongguo shehuidang, 74-76.
} 
aegis of the Beiyang government, no matter how wholeheartedly, complied with the ban. But Chen Jiongming did not. ${ }^{42}$

By 1920, Chen's anarcho-socialist Mecca in Fujian had become so influential that the British Consulate in Fuzhou demanded immediate attention and action of the Beiyang government. ${ }^{43}$ While the British counsellor Harold Harding became increasingly anxious about Chen Jiongming's unflinching endorsement of radical ideas and his unconventional political experiments, the "Huiming friends", who had scattered in Beijing, Shanghai, and Guangzhou after the death of Liu Shifu, were profoundly impressed and stimulated by Chen. In the "Statement of the Anarchist-Communist Comrades in Shanghai", a document that was confiscated by the head of Hunan Post Office, Chen Jiongming's efforts and attainments were paralleled with those of the “popular revolution” (pingmin geming 平民革命) in Europe:

To get rid of our moral hypocrisy and destroy the ancient system, we must initiate a thorough social revolution, reconstruct and reorganize [the society], and thereby realize real liberty and equality. [...] We need neither the Beiyang government nor the Guangzhou military government. [...] Russia has been transformed from an autocratic empire to a state of the working class; popular revolution is also thriving in Germany, driving out Wilhelm II; and the strikes in Hong Kong already pronounced the death of capitalists - this is not to mention that Mr. Chen Jiongming, holding ample military power, has launched Minxing in Zhangzhou to advocate social reforms and to challenge statist ideas. ${ }^{44}$

Such reciprocal recognition, mutual trust, and aspirational collaboration between Chen Jiongming and Chinese anarchist thinkers should be attributed not only to the solid friendships and native bonds they maintained with one another, but also to the common ideological and intellectual ground they found on the making of a modern Guangdong and modern China. Despite having been labelled by the Beiyang government as dangerous radicals, and regardless of their outspoken admiration for the popular revolution in Europe, neither Chen Jiongming nor his "Huiming friends" were willing to impose a Bolshevik-style revolution on China. Quite on the contrary, they adopted a moderate and reformist tone, adhered to a gradualist approach, and demonstrated meticulous concern for China's unique political and social conditions.

In line with Liu Shifu's interests in establishing a rural commune in Guangdong (which failed due to the crisis of the war against Yuan Shikai), Chen Jiongming perceived "local selfgovernance" (difang zizhi 地方自治) and “rural construction" (xiangcun jianshe 鄉村建設) as the first step towards building a federalist China. ${ }^{45}$ For Chen and his anarchist friends, Chinese villages constitute the natural testing ground for developing local self-governance and fulfilling

42 “Guangdong youwuzhang jianchu tichang wuzhengfu zhuyi yinshuawu bing qing tongxing chajin de wenshu” 廣東郵務長檢出提倡無政府主義印刷物並請通行查禁的文書, December 1921 to April 1922, the Second Historical Archives of China (SHAC), 1001 (2)960.

43 "Waijiaobu wei yanmi chajin Fujian Zhangzhou guoji zhuyi xuanchuanpin chuanbo youguan wenjian” 外交部為嚴密查禁福建漳州過激主義宣傳品傳播有關文件, April and May 1920, in Zhongguo wuzhengfu zhuyi he zhongguo shehuidang, 65-67.

44 "Hunan youwuzhang jianchu wuzhengfu zhuyi shukan bing qing tongxing chajin de wenshu” 湖南郵務長檢出無政府主義書刊並請通行查禁的文書, October 1921 to February 1922, SHAC, 1001 (2)-959.

${ }^{45}$ Krebs, Liu Shifu, Soul of Chinese Anarchism, 10 \& 117. 
anarchist reform, as the absence of political authority enables autonomous rural life and cultivates a caring, sharing and moral relationship among villagers. Drawing upon Tolstoyan and Kropotkinian ideas, they proposed to gradually construct a rural life in which mental and manual labour, agriculture and industry could be combined. ${ }^{46}$ Like the anarchists, Chen Jiongming also believed that democracy in China must evolve from rural communities and their tradition of self-rule. Chen's blueprint for a modern Guangdong and modern China, in this sense, not only emphasized a bottom-up and autonomous movement without centralized forces, but also projected a gradual and evolutionary progress without authoritarian intervention.

Positioning his anarcho-federalist ideas in opposition to any centralized mechanism imposing changes by force, Chen Jiongming questioned the authoritarian nature of modern nation-states and challenged the tenets of nationalism:

Nations are only transitory institutions in the evolutionary process of the world and are definitely unnecessary in its later stages of development. As a matter of fact, nationalism has been used by ambitious politicians as a way to fool their people and bully the world. [...] Once we have transformed our ideas, we will be able to create a new life and new institutions, and thus to build a new world where there are no national and racial boundaries, and no difference between "us" and "others". ${ }^{47}$

Notwithstanding such critiques, Chen Jiongming did not reject May Fourth nationalism. During the May Fourth Movement, he applauded the "citizens' gatherings" (guomin dahui 國 民大會) organized by students in Zhangzhou and reinforced local anti-Japanese protests. ${ }^{48}$ Winston Hsieh points out the dilemma facing Chen: On the one hand, as a proponent of anarchism and federalism, he launched a polemic against the thesis of nationalism; but on the other hand, his patriotic feelings constantly propelled him to criticise any deeds that might damage the national interest. ${ }^{49}$ In fact, Chen Jiongming's patriotic sentiment never contradicted his anarcho-federalist ideas because it was not detached from, but was rooted in, his persistent attachment to the region and the locale: Like other regional military leaders who supported May Fourth student movements such as Wu Peifu 吳佩孚, he demonstrated that “the love for one's native place is consistent with patriotic sentiment for the country." ${ }^{\circ 0}$ But unlike $\mathrm{Wu}$, he firmly advocated the primacy of "the regional and the local" in understanding and solving China's problems. To Chen Jiongming, although it appears that China had been under a monarchic despotic rule, the truth is that China was governed by rural gentries and local magistrates - reform and reconstruction should and can only be animated at the local level first, then pushed towards national and international levels. ${ }^{51}$

While Chen Jiongming's honest love of his native province was not at odds with his deep concern for the nation, nor did it prevent him from identifying with a utopian brand of

\footnotetext{
${ }^{46}$ Arif Dirlik, Anarchism in the Chinese Revolution (Berkeley and Los Angeles, California: University of California Press, 1991), 237-239.

${ }^{47}$ Chen Jiongming, “Minxing fakanci” 閩星發刊詞, 1919, in Chen Jingcun nianpu, 10061012; Chen, Chen Jiongming and the Federalist Movement, 83.

48 “Zhangzhou zhi guomin dahui” 漳州之國民大會, Shenbao, 5 June 1919, 2.

${ }^{49}$ Hsieh, "The Ideas and Ideals of a Warlord: Ch'en Chiung-ming", 221.

${ }^{50}$ Chen, "The May Fourth Movement and Provincial Warlords: A Reexamination", 150.

${ }^{51}$ Chen, Chen Jingcun nianpu, 214-215.
} 
internationalism. Such identification, as shown in his foreword to Minxing, is based on his faith in the power of intellectual transformation, which, as he believed, would stimulate sociocultural transformation and lead all mankind towards a boundless new world. ${ }^{52}$ In this regard, it was exactly because of the nexus between his anarchist, federalist and internationalist ideas, Chen Jiongming became no fan of the fashionable Bolshevism introduced to China since the Russian Revolution. To him, socialism was a universal value whose implementation in each country should respect their own current conditions. Centralized revolution and organized class struggle were not to his taste, nor were they discerned as suitable for China. ${ }^{53}$ Refusing to emulate Soviet Russia, Chen Jiongming, as we shall see in the next section, hoped to achieve a popular revolution through gradual local reform and genuine intellectual transformation, not by means of the dictatorship of one class.

\section{The Qunbao Society and a New Culture in Guangdong}

After the First World War, Chen Jiongming believed that China was faced with a burgeoning new world where all nations were seeking to attain “equal happiness" (jundeng xingfu 均等幸 福) among their citizens, and that the only way for China to catch up with this trend was by developing education. ${ }^{54}$ When he was still in Zhangzhou in late 1919, he had already telegraphed the Western Returned Students' Association in Guangdong (Guangdong xiyang liuxuesheng lianhehui 廣東西洋留學生聯合會), calling for their efforts to establish a university in Guangzhou. ${ }^{55}$ To solicit more support to his education reform, Chen Jiongming needed a strong cultural leader, a prominent figure of the New Culture Movement. ${ }^{56}$ Chen Duxiu, a renowned educator, dean of liberal arts of Peking University and a vociferous promoter of new culture, hence became the perfect candidate to stimulate the intellectual transformation that he desired. Unfortunately, after being imprisoned for three months for spreading radial pamphlets in Beijing, Chen Duxiu had just left Peking University and moved to Shanghai. And overwhelmed by his new life as well as by the onerous editing work of $L a$ Jeunesse 新青年 in the French Concession, Chen refused the invitation. ${ }^{57}$ But Chen Jiongming did not give up. As soon as he was appointed civil governor of Guangdong and moved back to Guangzhou in late 1920, he sent his second invitation letter. And this time, Chen Duxiu accepted it.

On 25 December 1920, Chen Duxiu arrived in Guangzhou and moved into a three-story house in Jiuqu Alley 九曲巷, close to Taikang Road 泰康路. He named his house "Beholding the Clouds" (Kanyunlou 看雲樓), presumably alluding to his interest in observing the surging "clouds" preceding the change of political weather in China. ${ }^{58}$ Clearly he had expected a longterm stay: Not only did he quickly move out from Great East Hotel and settled into his new

\footnotetext{
${ }^{52}$ Chen, "Minxing fakanci", 1006-1012.

${ }^{53}$ Liang Bingxian, Jiefang bielu 解放別錄 (Taipei: Wenhai Press, 1968), 14-15.

54 “Chen Jiongming fu Guangdong xiyang xuesheng lianhehui dian” 陳炣明復廣東西洋學生 聯合會電, Shenbao, 19 October 1919, 2.

55 “Chen Jiongming fu Guangdong xiyang xuesheng lianhehui dian”, 2; "Chen Jiongming yi ban hufa daxue dian”陳炣明議辦護法大學電, Shenbao, 27 October 1919, 3.

${ }^{56}$ Liang, Jiefang bielu, 18.

${ }^{57}$ Chen, Chen Jingcun nianpu, 215.

58 Tan Tiandu 譚天度, “Guanyu Guangdong dangzuzhi chengli de huiyi” 關於廣東黨組織成 立的回憶, in Tan Pingshan yanjiu shiliao 譚平山研究史料 (Guangzhou: Guangdong renmin Press, 1989), 381.
} 
home, but within just one month he also relocated La Jeunesse from Shanghai to Guangzhou, with a new editorial office set up at No. 26 Changxing Street 長興街. ${ }^{59}$ Accompanied by Grigory Voitinsky, one of the first Comintern representatives sent to China, Chen Duxiu's move to Guangzhou entailed not only an intellectual mission to develop education, but also a political task to extend communist networks in the South. ${ }^{60}$ Although it is uncertain to what extent Chen Jiongming was aware of the Comintern's political scheme, it is evident that, despite the inconsonance between his own anarcho-federalist ideas and Soviet Bolshevism, he immediately appointed Chen Duxiu chairman of the newly formed Guangdong Provincial Education Committee (Guangdongsheng jiaoyu weiyuanhui 廣東省教育委員會), and entrusted him with full responsibility of reforming education in Guangdong. ${ }^{61}$

The collaboration unfolded between the "two Chens" quickly appealed to other young intellectuals in Guangdong. Tan Pingshan 譚平山, Chen Gongbo 陳公博, and Tan Zhitang 譚 植棠, all natives of Guangdong Province, had just graduated from Peking University and come back to Guangzhou to establish their academic career. During their study between 1917 and 1920, the three of them lived in the same dorm room and had already acquainted themselves with Chen Duxiu - their academic leader and spiritual mentor. As soon as they returned to Guangzhou, they decided to launch a newspaper to spread new ideas and expand their intellectual networks. Not only did they receive ardent encouragement from Chen Duxiu, but they also gained political and financial support from their governor, Chen Jiongming. In October 1920, Guangdong Qunbao (hereafter Qunbao) was born. ${ }^{62}$

The principles of Qunbao were pronounced in the launch issue: First, to promote a new culture and to avoid discussing current political affairs; Second, to reject any request for political affiliation and to maintain the spirit of high intellectual independence. ${ }^{63}$ This declaration, to a great extent, resonated with Chen Jiongming's enthusiastic statement made one year ago for launching Minxing: "Our purpose is to revamp our thinking and create a new culture; our urgent task is to carry out an intellectual transformation." ${ }^{64}$ Liming 黎明, the daily supplement of Qunbao, features an image of a goddess looking woman, who wears a flowy Western-style dress with long, silky Chinese ribbons flying around her shoulders, and raises one arm high into the sunlight of early dawn. ${ }^{65}$ This image, reminiscent of Marianne in Eugène Delacroix's painting La Liberté guidant le peuple, indicates that the aim of Qunbao was not only to promote revolutionary ideas, but also to popularize the political thoughts and debates imported from the West and to expedite the birth of a new culture in Guangdong.

\footnotetext{
${ }^{59}$ Minguo Guangdong dashiji, 129; “Xinqingnian she qishi” 新青年社啟示, Guangdong Qunbao 廣東群報, 30 April 1921, unknown page.

${ }^{60}$ Liang, Jiefang bielu, 29-30.

${ }^{61}$ Shenbao Guangdong ziliao xuanji 申報廣東資料選集, edited by Guangdong Provincial Archives (Guangzhou: Guangdong Provincial Archives, 1995), 106.

${ }^{62}$ Tan Tiandu, "Yi Guangdong qunbao de chuangban he Guangdong dangzuzhi de dansheng" 憶廣東群報的創辦和廣東黨組織的誕生, in Tan Zhitang yanjiu shiliao 譚植棠研究史料

(Guangzhou: Guangdong renmin Press, 1997), 255-257.

${ }^{63}$ Tan, "Yi Guangdong qunbao de chuangban he Guangdong dangzuzhi de dansheng", 257.

${ }^{64}$ Chen, "Minxing fakanci", 1012.

${ }^{65}$ Collection of Guangdong Qunbao, January 1921 to May 1922. Guangdong Provincial Archives.
} 
Under the auspices of Chen Jiongming's governance, Guangzhou quickly became a May Fourth crucible. Following the establishment of Qunbao, other "new culture" organizations also flourished, including the Institution for the Cultivation of Propagandists (Xuanchuanyuan yangchengsuo 宣傳員養成所), the Institution for Chinese Character Romanization (Zhuyin zimu chuanxisuo 注音字母傳習所), and another newspaper called Labour Weekly (Laodongzhe zhoukan 勞動者周刊). ${ }^{66}$ Chen Jiongming's ambition for initiating a new culture was exalted in and out of Guangdong, and his efforts received wide public recognition. Not only did Qunbao continuously report on the governor's dedication to disarmament, civil governance, and education reform, but Shenbao 申報, the major newspaper of Shanghai, also highly praised the "bright future" brought about by him to Guangdong. ${ }^{67}$ According to Shenbao, the governor was determined to - by waging war against gambling and drugs while preaching a new culture - make Guangdong Province a brand new place. ${ }^{68}$ The formation of the Guangzhou Communist Cell in 1921 under Chen Duxiu's leadership, as we shall see in the remainder of this section, did not steal the spotlight from Chen Jiongming, neither did it reorient the making of new culture in Guangdong along Bolshevist lines.

In the spring of 1921, the Guangzhou Communist Cell was established, consisting of Chen Duxiu and the three other Qunbao members Tan Pingshan, Chen Gongbo, and Tan Zhitang. ${ }^{69}$ This political formation, however, did not make the Qunbao Society stand in opposition to the anarchist Huiming Society. Although Chen Duxiu had disclosed to Liang Bingxian his aspiration for 'solving all China's problems with Bolshevist spirit and method', he did not henceforth distance himself from the "Huiming friends" who were more enchanted with Chen Jiongming's anarcho-federalist blueprint than Bolshevism. Members of the two societies still met regularly at Chen's house, making plans together for transforming Guangdong. ${ }^{70}$ According to the memoir of Zheng Peigang 鄭佩剛, Qunbao and Labour Weekly, instead becoming organs of the Communist Cell, were the fruit of intense cooperation between Marxists and anarchists in Guangzhou. ${ }^{71}$ Despite his having denied the role played by anarchists in the founding of the Communist Cell, Tan Tiandu 譚天度 nonetheless admitted that, "We [Marxists] maintained a close friendship with the anarchists in Guangzhou, who were not considered by us as political rivals." 72 When Kropotkin passed away in Moscow, Cantonese anarchists organized a memorial meeting at the Grand Hall of Guangdong Senior Normal School. Among the more than 1,000 attendees were members of the Qunbao Society, who donated money for publishing a special commemorative issue for the event. Three months later, the May Day demonstration further showcased the fusion of Marxists and anarchists in leading

\footnotetext{
${ }^{66}$ Minguo Guangdong dashiji, 125.

67 “Guangzhou yi wu minjun zongji” 廣州已無民軍踀跡, Guangdong Qunbao, 5 January 1921, 3; “Shi jiaoyuju gaige jiaoyu zhi daguihua” 市教育局改革教育之大規劃, Guangdong Qunbao, 1 April 1921, 3; “Minzhi sheng zhong xinshizheng jinxing”民治聲中新市政進行, Guangdong Qunbao, 11 May 1921, 3; “Guangdong zuijin zhi minzhi guan” 廣東最近之民治 觀, Shenbao, 23 November 1920, 2; “Chen Jiongming yunren shengzhang hou zhi Guangzhou”陳畑明允任省長後之廣州, Shenbao, 13 November 1920, 2.

68 “Chen Jiongming yunren shengzhang hou zhi Guangzhou”, 2.

${ }^{69}$ Minguo Guangdong dashiji, 131.

${ }^{70}$ Liang, Jiefang bielu, 18.

${ }^{71}$ Zheng Peigang 鄭佩剛, “Zheng Peigang huiyi” 鄭佩剛回憶, in Tan Pingshan yanjiu shiliao, 404.

${ }^{72}$ Tan, "Guanyu Guangdong dangzuzhi chengli de huiyi", 383-384.
} 
a labour movement in Guangzhou. The demonstrators, comprising both Marxists and anarchists, raised aloft the huge portraits of Marx and Kropotkin side by side on Yonghan Road 永漢路. ${ }^{73}$

More importantly, Qunbao, instead becoming a communist institution, constituted an intricate political-intellectual network amongst Chen Jiongming and the May Fourth intellectual, and continued serving as an important platform for their idea exchange and political collaboration, far beyond the aegis of the Guangzhou Communist Cell. Between 1920 and 1922, the newspaper not only profoundly discussed different branches of socialist ideas, but also closely followed Bertrand Russell's and John Dewey's lecture tours in China, and explicitly celebrated the achievements of provincial self-governance movement (zizhi yundong 自治運動) in Hunan, Zhejiang, and Guangdong. ${ }^{74}$ Its chief editors, Tan Pingshan and Chen Gongbo, albeit being founding members of the Communist Cell, continuously pursued intellectual satisfaction outside the bounds of Soviet Bolshevism. In 1919, Tan Pingshan published a 15-page long article in New Tide 新潮 to air his views on the "worldwide democratic trend". Having classified the existing Western democratic experiences into four categories, namely political democracy in France, economic democracy in Great Britain, spiritual democracy in the United States, and social democracy in Germany and Soviet Russia, he praised German state socialism as the best form of social democracy, which, in his view, demonstrated a balance between nationalism and anarchism, as well as between national planning and individual freedom. The Soviet practice of social democracy, by contrast, "has led to factional conflicts, and subjected the nation to ravage and the people to an occupying power." ${ }^{75}$ Discussions over social transformation in Germany persisted within the Qunbao Society, as Tan Pingshan started a column called “Germany News Dispatch” (Deguo tongxun 德國通訊), introducing to his readers the new policies and praxis in Germany following the November Revolution. ${ }^{76}$ Chen Gongbo, the other editor, had always found academe more attractive than politics. When he was studying at Peking University, the mounting student movements of 1919 failed to transform him from a bookworm to a political activist - despite his high respect for Chen Duxiu, the only time he approached Chen was for seeking information about examination schedules. ${ }^{77}$ During his tenure as the chief editor of Qunbao, Chen Gongbo wrote numerous articles to reflect on the pressing issues pertaining to education, women's emancipation, and provincial election in Guangdong, engaging his readers with not only a wide range of topics, but also an expository rather than persuasive writing style. ${ }^{78}$

${ }^{73}$ Minguo Guangdong dashiji, 133; Tan, "Guanyu Guangdong dangzuzhi chengli de huiyi”, 405.

${ }^{74}$ For example, “Shehui zhuyi piping” 社會主義批評, Guangdong Qunbao, 19 January 1921, 3; “Huanying Dewey” 歡迎杜威, Guangdong Qunbao, 29 April 1921, 2; “Luosu zhi Ying Ri tongmeng tan” 羅素之英日同盟談, Guangdong Qunbao, 14 September 1921, 7; “Xiangren caibing zizhi xuanyan” 湘人裁兵自治宣言, Guangdong Qunbao, 28 September 1921, 7.

75 Tan Pingshan 譚平山, “demokelaxi zhi simianguan” 德謨克拉西四面觀, New Tide Vol. 1 Issue 5 (1919), 809-823.

76 “Jijin de shehuihua zhi Deguo - Deguo tongxun”激進的社會化之德國 - 德國通訊, Guangdong Qunbao, 18 March 1921, 8.

${ }^{77}$ Shi Yuanhua 石源華, Chen Gongbo zhegeren 陳公博這個人 (Shanghai: Shanghai renmin Press, 1997), 29.

${ }^{78}$ Chen Gongbo, “Zhongguo lishi shang de shehuigeming” 中國歷史上的社會革命, Guangdong Qunbao, 23 June 1921, 9; Shi, Chen Gongbo zhegeren, 40. 
According to Chen Gongbo, Qunbao could not have lasted long without the assistance provided by his colleagues from outside the Communist Cell. As professors teaching fulltime at local colleges, Tan Pingshan and Chen Gongbo had neither time nor money to sustain the publication of a daily newspaper. Relying on the meagre donations he had received from a few intellectual friends, Chen Gongbo had little confidence that Qunbao would survive, let alone grow to be the organ of the Communist Cell. Having heard about the crisis facing Qunbao, two friends hailing from the Huiming Society joined the editorial team: One was Chen Qiulin, the former editor of the anarchist magazine Minxing, and the other was Chen Yansheng 陳雁聲, a Cantonese anarchist affiliated with the KMT. Not only did the two newcomers take over most of the editorial work, but they also brought a promise of 2,000 yuan monthly subsidy to be provided by governor Chen Jiongming. ${ }^{79}$ Chen Gongbo felt so relieved to have part of his workload lifted off his shoulders: "Since Qiulin and Yansheng joined us, Tan Pingshan and I could focus on our teaching at university, and we only needed to come to office in the afternoon to write a few editorials." 80

While Chen Qiulin and Chen Yansheng promised that they would never turn Qunbao into a political organ singing high praises of the governor, it is nonetheless evident that the collaboration between Chen Jiongming and the May Fourth intellectual has further materialized through the publications of Minxing and Qunbao. ${ }^{81}$ Without the continuous financial and institutional support offered by Chen Jiongming, it would be unthinkable for these men of letters to settle down in Guangzhou, to secure a position in the field of education, to give talks and publish in public, or to maintain their high intellectual independence. Despite the formation of the Guangzhou Communist Cell, the Qunbao Society did not assert their absolute authority over the making of new culture in Guangdong, nor did they lessen their idea exchange and political collaboration with Chen Jiongming: Chen Duxiu continued his services to the Guangdong Provincial Education Committee; he and his peers retained close relationships with the anarchist thinkers in Guangzhou who were ideologically closer to Proudhon than to Marx; and most importantly, echoing Chen Jiongming, the Qunbao Society embraced an eclectic mix of ideas and dedicated their efforts to intellectual transformation. Such collaboration, as the next section will show, was neither a convenient option nor a contingent offer. Quite on the contrary, it entailed a high degree of personal commitment and dedication from both sides, which could not be explained by the "pragmatic calculation and short-run considerations" of Chinese warlordism. ${ }^{82}$

\section{Ideological Consonance, Personal Commitment, and the Ambiguous "Anti- Warlordism"}

Political collaboration between the "two Chens" was not simply a matter of mutual benefit for the man of guns to demonstrate his political charisma while the man of letter to obtain institutional and financial support. Ideological closeness, if not complete consonance, between the two was also crucial to the development of their relationship. Before Chen Duxiu's arrival in Guangzhou, he had already begun correspondence with Chen Jiongming, and their idea

\footnotetext{
${ }^{79}$ Liang, Jiefang bielu, 31. However, according to Chen Gongbo, the amount of monthly subsidy provided by Chen Jiongming was 300. Chen Gongbo, "Wo yu Gongchandang" 我與 共產黨, in Tan Pingshan yanjiu shiliao, 415.

${ }^{80}$ Chen, "Wo yu Gongchandang", 415.

${ }^{81}$ Chen, "Wo yu Gongchandang", 414-415.

${ }^{82}$ Pye, Warlord Politics, 10.
} 
exchange was further cemented by Dai Jitao 戴季陶, then a Marxist activist in Shanghai and founding member of the Shanghai Communist Cell. Thinking highly of Chen Jiongming, Dai called Chen "a socialist general" and was passionate about conducting socialist experiments in Zhangzhou, the anarcho-socialist Mecca. ${ }^{83}$ Although Chen Duxiu had been hesitant to go along with Dai's plan and rejected the first invitation from Zhangzhou, he nonetheless perceived local self-governance as the foundation of democracy. In his article "The Foundations for Establishing Democracy" published in La Jeunesse in 1919, Chen Duxiu applauded American federalism and advocated a type of absolute self-governance to be carried out by autonomous micro-organizations formed among local people. ${ }^{84}$

Although it is hard to discern to what extent Chen Duxiu's pro-anarchist and pro-federalist political view at this time was fruit of his correspondence with Chen Jiongming, it is certain that as soon as he arrived in Guangzhou, he explicitly acknowledged his approval of Chen Jiongming's rule. In his article "Welcome the New Army", printed on the frontpage of Qunbao on the New Year's Day of 1921, he distinguished between the "old-style, private army" running at the personal whim of warlords such as Duan Qirui 段祺瑞 and Zhang Zuolin 張作霖 and the "new-style, public army" serving the collective interest of society. The Cantonese army led by Chen Jiongming was then hailed as one that showed the greatest potential to become a new army equipped with "new ideas of the new era". ${ }^{85}$ By celebrating the Cantonese army, Chen Duxiu expressed his trust in Chen Jiongming, who was expected to become not only a new type of military leader but also an innovative reformer. And Chen Jiongming, by providing his honoured guest with unconditional support and an autonomous working environment, lived up to such high expectations. He made promises about the independence of educational institutions and non-interference in personnel matters. ${ }^{86} \mathrm{He}$ also ensured that education projects were always prioritized, and funds were efficiently raised for establishing a new normal school, a new student dormitory, a printing house, and university foundation courses in Guangzhou. The annual budget allocated to developing education also increased from 200,000 to three million in 1921. ${ }^{87}$ Although the Guangdong Provincial Legislative Assembly (Guangdong shengyihui, 廣東省議會) had vetoed the proposal to establish co-education at Guangdong Senior Normal School, the governor insisted on protecting women's right to higher education as a crucial part of education reform and cultural renewal. ${ }^{88}$

However, the new culture preached by Chen Duxiu in Guangzhou was not to everyone's taste. Not long after his arrival, the streets were full of leaflets demonising him and denouncing his ideas pertaining to socialism and women's emancipation. For many people, the new culture epitomized by Chen's ardent advocacy of co-education, mass labour movement, and women's movement - was not "democracy and science", but Soviet Bolshevism. Lucky for Chen Duxiu, Chen Jiongming stood firm in his support and instated a ban on such leaflets. ${ }^{89}$ No sooner did they get out of one trouble than they encountered another. The Guangzhou-Zhaoqing Native-

\footnotetext{
${ }^{83}$ Zhang Guotao 張國壽, Wo de huiyi 我的回憶 (Beijing: Dongfang Press, 1998), 47.

${ }^{84}$ Chen Duxiu, “Shixing minzhi de jichu” 實行民治的基礎, La Jeunesse Vol. 7 Issue 1 (1919), 13-21.

85 “Huanying xinjunren” 歡迎新軍人, Guangdong Qunbao, 1 January 1921, 1.

${ }^{86}$ Zeng, "Chen Duxiu yu Chen Jiongming guanxi kaoxi”, 17.

87 “Chen shengzhang biaoshi xingxue zhi juexin”陳省長表示興學之決心, Guangdong

Qunbao, 16 May 1921, 3; Zeng, "Chen Duxiu yu Chen Jiongming guanxi kaoxi”, 17.

88 “Guangdong zuijin zhi minzhi guan”, 2.

${ }^{89}$ Minguo Guangdong dashiji, 131.
} 
Place Society in Shanghai telegraphed Chen Jiongming, repeatedly, accusing Chen Duxiu of "disturbing the society and deceiving the people" and demanding his immediate expulsion from Guangdong. ${ }^{90}$ Without hesitation, Chen Jiongming jumped to Chen Duxiu's defence again: "Mr. Chen Duxiu is the greatest educator of our times and a noble-minded person. Any negative news you might hear about him are nothing but rumours." 91

Objections also arose from within the revolutionary camp. Chen Duxiu's activism in Guangdong was not only thwarted by those who attempted to preserve the old social structure, but also frowned upon by some KMT veterans, who, as Fitzgerald asserts, held more enthusiasm for realpolitik than for the new culture and thus were eager to curtail the increasingly influential alliance between Chen Jiongming and Chen Duxiu. ${ }^{92}$ In March 1921, Chen Duxiu engaged in an intense debate with Xia Chongmin, managing director of the KMT organ Guangzhou Chenbao 广州晨报, about organising student movement for co-education. While Chen Duxiu clamoured for promoting a co-education movement in Guangzhou, Xia did not see student movement as the way necessary to achieve co-education. The debate ended so badly that Xia lodged an official complaint in writing in Guangzhou Chenbao to embarrass Chen Duxiu by commenting on the "several things" that Chen had done. And Chen, in return, issued a statement in Qunbao, accusing Xia of deliberately damaging his reputation and asking Xia for evidence. ${ }^{93}$ Concerning the deteriorating antagonism between the two, Qunbao interviewed Wang Jingwei 汪精衛, the honorary president of the Guangdong Provincial Education Committee and a close advisor to the Guangzhou government, to seek his opinion. Instead of disclosing his own thoughts, Wang commented on Chen Jiongming's commitment to co-education and accentuated the governor's deep trust in Chen Duxiu. "It would be very embarrassing", said Wang to the journalist, "if Mr. Chen Duxiu suffered from these unreasonable attacks and eventually decided to leave Guangzhou." ${ }^{94}$ While Wang Jingwei might have simply provided a courteous, perfunctory statement on this matter, his answer nonetheless implies his sensitivity to, if not concern of, the tight bond between the "two Chens". Other KMT leaders were certainly less courteous while venting their dissatisfactions with Chen Duxiu. As revealed by Chen Gongbo, both Hu Hanmin 胡漢民 and Liao Zhongkai 廖仲恺 had made some derogatory comments, which deeply upset Chen Duxiu and eventually prompted his departure from Guangzhou. ${ }^{95}$

Despite Chen Jiongming's unwavering support, the pervasive opposition to his activism in Guangdong finally made Chen Duxiu consider resigning from his position. In July 1921, after he had been elected in absentia the first General Secretary of the newly founded CCP in Shanghai, leaving Guangzhou became necessary. His first resignation letter, delivered to Chen Jiongming on 24 August, was immediately rejected. ${ }^{96}$ The governor composed a heart-felt, emotive reply in attempting to persuade Chen Duxiu to stay: "Although facing the storm alone,

\footnotetext{
${ }^{90}$ Minguo Guangdong dashiji, 133.

${ }^{91}$ Chen, Chen Jingcun nianpu, 320.

${ }^{92}$ Fitzgerald, Awakening China, 194 \& 198-199.

93 “Jiu nannü tongxiao wenti zhankai zhenglun” 就男女同校問題展開爭論, Guangdong Qunbao, 3 March 1921, 2.

94 “Wang Jingwei zhi nannü tongxiao tan” 汪精衛之男女同校談, Guangdong Qunbao, 5 March 1921, unknown page.

${ }^{95}$ Liu Juan 劉娟 and Yuan Zheng 袁征, “1921 nian Guangzhou gejie qu Chen shimo” 1921 年廣州各界驅陳始末, Xueshu yanjiu 04 (2014), 100.

${ }^{96}$ Minguo Guangdong dashiji, 138.
} 
we must adhere to our plan and continue our work. As to the obstacles, I will clear them for you." ${ }^{, 97}$ But Chen Duxiu had made up his mind. In September 1921, after staying for nearly nine months, Chen Duxiu left Guangzhou, despite Chen Jiongming's unwillingness. ${ }^{98}$ It might seem only "natural" that, after Chen Duxiu's departure and especially after the coup d'état, members of the Guangzhou Communist Cell, who were then the founding leaders of the CCP, would yield to the Comintern's demands and align with Sun Yat-sen in initiating the National Revolution. But as the remainder of this article will show, collaboration between Chen Jiongming and the May Fourth intellectual did not suddenly terminate due to Chen Duxiu's departure. Even after the coup d'état, the attitude of China's prominent thinkers towards Chen Jiongming - the now condemned "warlord" - was extremely ambiguous.

In April 1922, having failed to persuade Sun Yat-sen to discard his plan for the Northern Expedition, Chen Jiongming resigned from his official, if not nominal, positions within the Guangzhou government, albeit still enjoying the loyalty of his army that had followed him since the revolutionary period. ${ }^{99}$ He left for Huizhou, a small town to the east of Guangzhou, where he expected to shun turmoil nearby the beautiful western lake and to reflect on the "mistakes" he had made in the past years. ${ }^{100}$ Unfortunately, his "meditation" in exile was soon interrupted by different groups of KMT notables who came to persuade him to reconcile his relationship with Sun Yat-sen. Leaders of the Guangzhou Communist Cell were also amongst these persistent lobbyists. In early May, Chen Duxiu and Chen Gongbo, on the heels of many KMT officials before them, arrived in Huizhou. Their effort to talk Chen Jiongming into joining the CCP and contributing to the Northern Expedition was, however, made in vain. The "socialist general" was extremely stubborn about his own ideas, insisting that socialist reform should begin with education and that no one should capitalize on labour movement for fulfilling personal political ambition. ${ }^{101}$

It is not hard to understand Chen Jiongming's reluctance to join the Northern Expedition. As Fitzgerald argues, he feared that Sun Yat-sen would try to impose party rule on the province from a more secure position after a successful military manoeuvre and thus his own blueprint for federalism and provincial self-governance would abort. ${ }^{102}$ Perhaps more importantly, he also feared that Sun would rely on military force to hasten the birth of revolution at the expense of enlightenment and thereby the new culture sprouting in Guangzhou - through education reform and intellectual transformation as he desired - would come to an end. What is difficult to discern, however, is Chen Duxiu's personal attitude towards the anarcho-federalist blueprint and towards Chen Jiongming, which has shifted profoundly as a result of his increasing identification with Marxism during the May Fourth period. ${ }^{103}$ It is impossible to identify a "turning point" regarding the relationship between Chen Duxiu and Chen Jiongming: Was it the spring of 1920 when Chen Duxiu "embraced Marxism enthusiastically", or the summer of 1921 when he was elected the head of the CCP? ${ }^{104}$ Was it the spring of 1922 when he failed to

\footnotetext{
${ }^{97}$ Zeng, "Chen Duxiu yu Chen Jiongming guanxi kaoxi”, 17.

${ }^{98}$ Minguo Guangdong dashiji, 139; Chen, Chen Jingcun nianpu, 391.

${ }^{99}$ Minguo Guangdong dashiji, 150.

100 “Baihuazhou shang zhi Chen Jiongming” 百花洲上之陳炣明, Guangdong Qunbao, 5 May 1922, 6.

${ }^{101}$ Minguo Guangdong dashiji, 150-151.

102 Fitzgerald, Awakening China, 152.

${ }^{103}$ Hung-yok Ip, Intellectuals in Revolutionary China, 1921-1949: Leaders, Heroes and Sophisticates (Abingdon: Routledge, 2004), 27-28.

${ }^{104}$ Ip, Intellectuals in Revolutionary China, 1921-1949, 28.
} 
convert Chen Jiongming, or one month later when the coup d'état finally occurred? - Perhaps all of these combined, or perhaps none of them. It was not until after the second CCP congress had expressed the Party's commitment to forming an "anti-warlordism" united front, that Chen Duxiu finally - one year after he had left Guangzhou and three months after the coup d'état launched a polemic against Chen Jiongming. In his article published in September 1922, he harshly criticised federalism and provincial self-governance as ideas that would only provide legitimacy and constitutional protection to warlord rule. ${ }^{105}$

The other members of the Qunbao Society, namely Tan Pingshan, Chen Gongbo, and Tan Zhitang, were even more dubious about ending their collaboration with Chen Jiongming. After the CCP was officially established, the Central Committee of the Party had repeatedly sent letters and telegrams to the Guangzhou Communist Cell, urging the leaders to support Sun Yatsen instead of Chen Jiongming. But the Party's order seemed to have fallen on deaf ears. The comrades in Guangzhou continued 'believing in Chen Jiongming's capability while despising Sun's empty words ${ }^{106}$ In his report to the Comintern Cai Hesen 蔡和森 commented at length on the "mistakes" made by the Guangzhou Communist Cell during the heightened conflicts between Chen and Sun:

The comrades in Guangzhou were very strange: They held a sympathetic attitude towards Chen Jiongming. Their group, the Guangdong Qunbao, were leaning towards Chen. [...] The Central Committee had sent letters to criticise Gongbo and Pingshan, and later those comrades who had been affiliated with Chen Jiongming were transferred back to Shanghai. ${ }^{107}$

According to Cai's report, it was because of their persistent collaboration with Chen Jiongming that the comrades in Guangzhou were harshly punished: Not only was Chen Gongbo expelled and Tan Pingshan transferred away, Tan Zhitang was also removed from the Party at the same time. ${ }^{108}$ Warnings and punishments, however, did not seem to make Chen Gongbo and Tan Zhitang reflect on and rectify their "mistakes". On the contrary, in September 1922, they launched a new magazine in Guangzhou, Zhujiang Pinglun 珠江評論, to comment on current affairs outside the aegis of the CCP. While they lamented the chaos in Guangdong following the coup d'état, they did not denounce Chen Jiongming as the CCP had urged them to do. Rather, Zhujiang Pinglun adopted a neutral position and advised Chen Jiongming to enunciate his own political stance, ideas, and policy so as to stabilize the situation in Guangdong. ${ }^{109} \mathrm{In}$ the eyes of the CCP, this "impartial" voice nonetheless aided Chen Jiongming as well as his "warlordism". 110

${ }^{105}$ Chen Duxiu, “Duiyu xianzai zhongguo zhengzhi wenti de wojian” 對于現在中國政治問 題的我見, The Endeavour, 3 September 1922, in Hu Shi wencun 胡適文存 Volume 3

(Beijing: Central Compilation \& Translation Bureau, 2004), 119-128.

${ }^{106}$ Bao Huiseng 包惠僧, “Guanyu Tan Pingshan de huiyi” 關于譚平山的回憶, in Tan Pingshan yanjiu shiliao, 424.

${ }^{107}$ Cai Hesen, “Zhongguo gongchandangshi de fazhan” 中國共産黨史的發展, in Tan Pingshan yanjiu shiliao, 431.

${ }^{108}$ Cai, "Zhongguo gongchandangshi de fazhan", 431-432.

109 “Yulun” 輿論, Zhujiang Pinglun, Issue 3, 15 October (1922), 17-18.

${ }^{110}$ Cai, "Zhongguo gongchandangshi de fazhan", 431. 
The Endeavour 努力周報, a journal launched by Hu Shi 胡適 in Beijing, joined Zhujiang Pinglun in acknowledging Chen Jiongming's political and ideological strength. Two months after the coup d'état, Hu Shi invited Tan Pingshan to comment on the split between Chen Jiongming and Sun Yat-sen. In his long article published in The Endeavour, Tan Pingshan delineated the profound political and ideological differences between the two leaders and identified the major mistake made by Chen Jiongming:

In my opinion, if Chen Jiongming believed that his political ideas were different from those of Sun, he should have broken up with Sun by refusing to accommodate Sun's government when Sun returned to Guangdong [in 1920], by declining Sun's invitation to join the KMT, or by rejecting Sun's election [in 1921]. If Chen disapproved of Sun's plan for the Northern Expedition, he should have directly broken up with Sun by making a clear statement, withdrawing from the KMT, or sending ultimatum to Sun. ${ }^{111}$

In other words, the mistake made by Chen Jiongming was not that he broke up with Sun Yatsen, but that he did not do so much earlier and in a more decisive way. This view certainly departed from that of the CCP, who asserted that "Chen Jiongming had been a good revolutionary during the 1911 Revolution and during the time he stationed in Zhangzhou, [...] but when he thwarted the Northern Expedition and drove out Sun Yat-sen, he turned himself into an anti-revolutionary." 112 In contrast to the labels attached to Chen Jiongming by the CCP and the KMT - "anti-revolutionary", "spy working on behalf of international imperialism", and "feudalist warlord" - labels that were assertive and vague at the same time, Tan Pingshan's evaluation of Chen Jiongming was far more implicit and personal: "He was a very perseverant person, but just not decisive enough." ${ }^{113}$ Reading between the lines, one would be able to discern Tan's high hope for as well as deep disappointment in Chen Jiongming: If Chen had pronounced his own political ideas more explicitly and resisted Sun Yat-sen's plan more firmly, he would have been able to form his own political party and become a more successful initiator - military, political, and ideological - of the Chinese Republic.

The pro-Chen Jiongming tone of Zhujiang Pinglun and The Endeavour resonated with the rising federalist movement across China in 1922 and disturbed Sun Yat-sen's dream of cementing one-party rule with the help of the Comintern. Clearly, resisting Sun's military and political manoeuvres were not only those men of guns who were targeted as warlords, but also the men of letters who questioned Sun's capability and disapproved of the timing, style and goal of the revolution that he called for. Hu Shi made it clear that, the fact that Sun Yat-sen had rejected provincial self-governance and desired to unify the country by force of arms - that is, by allying with a small subset of military strongmen to defeat the rest - made his political policy no different from that of a northern military tyrant. ${ }^{114}$ Cai Yuanpei also concerned that Sun's revolution to topple the Beiyang government and to restore the Constitution had now

\footnotetext{
111 Tan Pingshan, “Ji Sun Chen zhi zheng” 記孫陳之爭, The Endeavour, Issue 16, 20 August (1922), 1-4.

${ }^{112}$ Sang Bing 桑兵, “Chen Jiongming shibian qianhou de Hu Shi yu Sun Zhongshan” 陳昫明 事變前後的胡適與孫中山, Modern Chinese History Research 03 (2001), 84.

113 Tan, "Ji Sun Chen zhi zheng", 2. For more information regarding the denunciation of Chen Jiongming by both the KMT and the CCP following the coup d'etat, see Goikhman, "Chen Jiongming, Becoming a warlord in Republican China", 85-93.

${ }^{114} \mathrm{Hu}$ Shi, “Zhe yi zhou” 這一周, in $\mathrm{Hu}$ Shi wencun Vol. 3, 215-216.
} 
degenerated into a war to seize the presidency. ${ }^{115}$ Although Zhang Taiyan 章太炎, a master of Confucian classics and forerunner of the 1911 Revolution, had preferred Sun to the northern military strongmen, he also held a lukewarm if not derogatory attitude towards the Northern Expedition. As a tenacious proponent of federalism and provincial autonomy, Zhang believed that the national constitution, the parliament, and the presidency were the "three most lethal viruses" (sandu 三蛽) menacing China because they would lead China either to a centralist system or to endless wars. ${ }^{116}$ In his letter to Chen Jiongming after the coup d'état, instead of criticising Chen, Zhang asked, earnestly: "Please tell me, have you relinquished your federalist ideas and abandoned the people of the South?" 117 In his reply to Zhang Taiyan, Chen Jiongming once again expressed his adherence to his own blueprint for a modern Guangdong and modern China:

I promoted federalist movement and advocated provincial self-governance, but I never thought that we would end up in this chaos! For China, I shall never cease my endeavour until my ideas are realized, no matter at all if I am a highly positioned official or I am just an ordinary citizen. ${ }^{118}$

The year 1922, in this case, may have witnessed the end of personal relationship between Chen Jiongming and Sun Yat-sen, but it certainly did not see the end of political and intellectual efforts to remould China along anarchist and federalist lines. Neither did the events between 1919 and 1922 signify the inevitable success of a Soviet-style revolution in China, to be followed by the birth of a centralized party-state. Chen Duxiu's belated call for "antiwarlordism" failed to generate a consensus in the intellectual circles. While Chen Duxiu eventually turned his back on Chen Jiongming as well as on anarchism and federalism, many of his May Fourth peers demonstrated strong faith in provincial self-governance as a gradual and peaceful path towards Chinese state-building. Instead of simply equating federalism with warlordism, Hu Shi, in his response to Chen Duxiu's denunciation of Chen Jiongming, pointed out: "The root of warlordism in China lies in nothing else but the desire for national unification by force of arms." 119 Taking one step further, Hu stated that, "China is too big to maintain a unitary political government; [...] only a federal political system based on provincial selfgovernance will be our weapon to fight warlordism." 120 This view, expressed by Hu Shi, one of the most eminent May Fourth intellectuals, echoed Chen Jiongming's anarcho-federalist blueprint, which had been unfolded to Rodney Gilbert one year and a half ago.

\section{Conclusion}

The aim of this research is not to convince the reader that Chen Jiongming was not a "feudalist warlord" - this job has been convincingly done by Hsieh, Duara, Fitzgerald, and Goikhman, as well as by Chen Jiongming's son Chen Dingyan. This research, more importantly, inquiries

115 “Cai Yuanpei fu Zhang Bingling Zhang Ji dian” 蔡元培復張炳麟張繼電, Shenbao, 14 June 1922, 2.

116 Zhang Taiyan nianpu changbian 章太炎年譜長編, edited by Tang Zhijun 湯志鈞

(Beijing: Zhonghua shuju, 2013), 369.

${ }^{117}$ Zhang Taiyan nianpu changbian, 368.

${ }^{118}$ Zhang Taiyan nianpu changbian, 372.

${ }^{119} \mathrm{Hu}$ Shi, “Lianshengzizhi yu junfageju - da Chen Duxiu” 聯省自治與軍閥割據 - 答陳獨

秀, The Endeavour, 10 September 1922, in Hu Shi wencun Vol. 3, 109-110.

${ }^{120} \mathrm{Hu}$, "Lianshengzizhi yu junfageju - da Chen Duxiu", 110 \& 119. 
into what Chen Jiongming really was, not only in terms of his identification with the New Culture and May Fourth movements, but also regarding the ways in which the May Fourth intellectuals identified with him through their idea exchange and political collaboration. Chen Jiongming held many seemingly contradictory characteristics: He possessed high military capabilities but enjoyed his own ideological, intellectual and cultural roles in the making of a modern Guangdong and modern China. Valued by him was not the military conquest, but the "transformation of ideas", which, to him, could only be achieved through creating a tolerant, liberal cultural space appealing to China's most innovative minds, through cultivating a print culture to engage the public, and through initiating a new way of life - from a new park to a new university, and from co-education to provincial election - in the region under his jurisdiction. He demonstrated deep loyalty to his native province, but he was not interested in any parochial, nativist policies that might isolate the province from the rest of China and the world. His constant pursuit of a universal model of "socialism" - that is, a system tolerating rather than depressing local diversity and autonomy - made him a fan of anarchism and federalism, but not Bolshevism. While he, like most May Fourth thinkers, adopted the Western notions of "modernity" in terms of political democratization and social reform, he retained his sensitivity if not resistance to total abandonment of the Chinese tradition. His profound admiration for the tradition of self-rule in rural China and his idealistic imagination of an absolutely free, equal, and harmonious world similar to Kang Youwei's "Grand Commonality" suggest a continuous reconciliation between Western liberalist ideas and Confucianist-Taoist philosophy that has been central to his anarcho-federalist blueprint. ${ }^{121}$

From October 1920 when Chen Jiongming was appointed civil governor of Guangdong to June 1922 when the coup d'état against Sun Yat-sen occurred, in less than two years Guangzhou witnessed significant political as well as cultural transformations. Liang Bingxian and Chen Duxiu worked side by side with Chen Jiongming and were entrusted with the mission of reforming education in the region under Chen's control. And with Chen's tenacious support, the May Fourth intellectuals in Guangdong, despite their different interpretations of "socialism" and divergent imaginations of the Chinese revolution, extended their networks and influence. Not only did they launch several newspapers to promote a new culture, but they also gave speeches and organized night classes, parades, demonstrations, and other events to engage the public. The "Huiming friends", many of whom had drifted away from the anarchist society after the death of Liu Shifu, first gravitated to the anarcho-socialist Mecca and later restored their network under the Socialist League in Guangzhou. And the Marxist-oriented intellectuals, most of whom had freshly graduated from Peking University, also benefited from the relatively tolerant, liberal environment in Guangzhou and established both the Qunbao Society and the Guangzhou Communist Cell. Only when placed amongst the May Fourth intellectual and perceived as an active agent of the Chinese enlightenment, Chen Jiongming would regain the essential part of his identity that has been long denied due to the dominant discourses on the Chinese revolution: He was a chatty friend to Liang Bingxian, a supportive, considerate boss to Chen Duxiu, a loyal comrade to the "Huiming friends", and a reliable patron to the Qunbao Society. He positioned himself so comfortably between the man of guns and the man of letters that the boundary between the two was no longer visible to his contemporaries. The idea exchange and political collaboration between him and the May Fourth intellectual, therefore, were conducive to and in the meantime a constitutive part of the ideological, intellectual and cultural innovations in the May Fourth period.

${ }^{121}$ For more information on Kang Youwei's "Grand Commonality", see Peter Zarrow, After

Empire: The Conceptual Transformation of the Chinese State, 1885-1924 (Stanford, California: Stanford University Press, 2012), 24-55. 
Their collaboration, however, was by no means simply contingent or pragmatic. As shown by this research, such collaboration was, on the one hand, based on their frequent exchange of thoughts, profound mutual understanding and support, and their shared aim to reform Guangdong and to create a new culture. On the other hand, it was achieved through their intertwined network of native-place linkages and teacher-student ties. Chen Jiongming, in this sense, was not only a political initiator who kept employing different ideas to navigate his reform, but also a network linchpin who tied together intellectuals of different political camps. Directly or indirectly, he garnered support from not only intellectuals located on the radical end of the political-intellectual spectrum, but also those who were more moderate regarding their attitude towards the means through which social, political and intellectual transformation should be realized in China, such as Hu Shi, Cai Yuanpei, and Zhang Taiyan. Even after the fatal split between Chen Jiongming and Sun Yat-sen, these May Fourth intellectuals, instead of immediately jumping on the bandwagon of Sun's National Revolution and of the KMT-CCP United Front, maintained an ambiguous if also sympathetic attitude towards Chen Jiongming.

While Chen Jiongming might be unique regarding the ways in which and the extent to which he engaged the May Fourth intellectual, he was certainly not the only one who transgressed the boundary between the man of guns and the man of letters. Firstly, many other regional leaders in South China celebrated federalist ideas. Zhao Hengti 趙恒惕, the military strongman of Hunan, not only frequently communicated with Chen in realising provincial self-governance in South China, but also collaborated with local intellectuals in promulgating the Huanan Provincial Constitution. ${ }^{122}$ Secondly, Chen Jiongming's anarcho-federalist blueprint was not the only available plan for state-building proposed outside the aegis of the KMT and the CCP. While Chen's diligent advocacy of a Chinese federation was echoed in most southern provinces, it encountered strong opposition from northern powers. The northern Zhili-clique strongman $\mathrm{Wu}$ Peifu, the first Chinese face to be put on the cover of Time magazine, was keen to remould the young Republic based on a blueprint that would provide balance between Western republicanism and Confucianism, and that aimed at a unitary Chinese state rather than a Chinese federation. Wu's regime engaged many moderate intellectuals with Anglo-American educational background, including Hu Shi and Cai Yuanpei, who in 1922 initiated a bit-by-bit political reform within the Beiyang government, with Wu's support. ${ }^{123}$ This research, therefore, instead of indicating that Chen Jiongming was either representative or exceptional, only serves as the first step towards reappraising the complex interactions between the man of guns and the man of letters in the fragmented processes of Chinese state-building after the 1911 Revolution, as well as towards rethinking the category of "warlord" and the dynamism of "warlordism" within the context of the Chinese enlightenment.

122 “Xiangsheng jinxing liansheng huiyi zhi jingguo”湘省進行聯省會議之經過, Shenbao, 2 August 1922, 2; Duara, Rescuing History from the Nation, 188-193.

123 “Wu Peifu jiang fabiao shiju yijian” 吳佩孚將發表時局意見, Shenbao, 13 May 1922, 2; Hu Shi, “Women de zhengzhi zhuzhang” 我們的政治主張, The Endeavour, Issue 2, 14 May (1922), 1. 